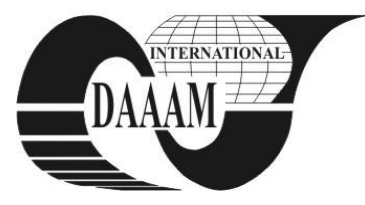

Annals of DAAAM for 2011 \& Proceedings of the 22nd International DAAAM Symposium, Volume 22, No. 1, ISSN 1726-9679 ISBN 978-3-901509-83-4, Editor B. Katalinic, Published by DAAAM International, Vienna, Austria, EU, 2011 Make Harmony between Technology and Nature, and Your Mind will Fly Free as a Bird Annals \& Proceedings of DAAAM International 2011

\title{
DIAGNOSTIC SYSTEM FOR FIRE RESISTANCE CABLES
}

\author{
DONCUK, J[an] \& MENTLIK, V[aclav]
}

\begin{abstract}
This paper deals with diagnostic of fire resistance cables. These cables are insulated by composite insulation. A composite tube ensures fire resistance barrier to supply safety devices in case of fire for sufficient time. Diagnostic is the key to determining properties of cables. Fire resistance cables which can be applied to nuclear energetics must meet the criteria laid out by International Atomic Energy Agency IAEA. One of these criteria is elongation at break which must be at least $50 \%$. Elongation at break was chosen as a diagnostic quantity. The diagnostic system is determined in the final part of this paper.
\end{abstract}

Key words: fire resistance cable, composite insulation, elongation at break, mica-glass tape

\section{INTRODUCTION}

Fire resistance cables are used in safety devices to supply energy in order to fire for sufficient time. These cables are insulated by composite insulation which ensures a fire resistance barrier (Moore, 1997). Mica-glass tape is used as composite insulation and it is applied by tapping. There is outer insulation extruded at this mica-glass tape. Outer insulation is made of halogen free material e.g. cross-linked polyethylene XLPE. Diagnostic of fire resistance cables determines properties of cables. One of these properties is elongation at break which has to be at least $50 \%$ according to IAEA (IAEATECDOC-1188, 2000).

\section{FIRE RESISTANCE CABLE}

Fire resistance cable is shown in figure 1 . The core of cable is tapped by mica-glass tape. Additional insulation is extruded on this tape and it is made of halogen free material. Insulated conductors are twisted around into the cable core. Due to this twisting around the cable conductors there is asymmetry in the cable core which must be fulfilled by halogen free material. The cable core is covered by cable sheathing which is also made of halogen free material.

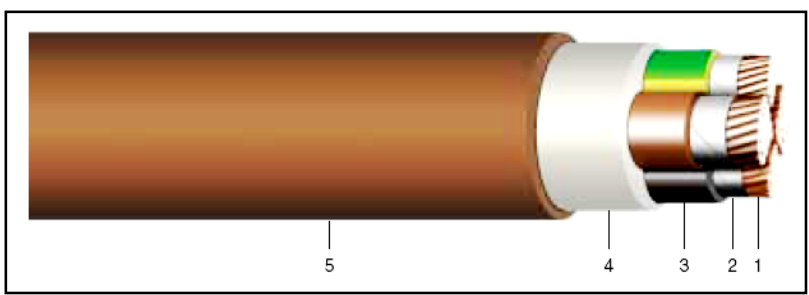

Fig. 1. Fire resistance cable: 1 - core, 2 - mica-glass tape 3 - insulation of core, 4 - intercore insulation, 5 - cable sheathing

\section{COMPOSITE INSULATION}

Composite insulation is composed of mica-glass tape and insulation of the core which is made of halogen free material. The core is tapped by mica-glass tape and insulation of the core is extruded on this tape. There are some basic requirements for tapping e.g. fixed and steady tapping with required ratio of covering (usually $25-50 \%$ ). The tape has to be turned around without wrinkles with defined and constant tension. The tapping is made by an insulation device. When the core is tapped by mica-glass tape insulation of core is applied. Halogen free material as plastic is extruded by extruder as a weldless tube. Insulation of the core is usually made of cross linked polyethylene XLPE or halogen free fire retardant material based on polyolefin's.

\section{MICA-GLASS TAPE}

Mica-glass tape is the most important part of the fire resistance cables because it ensures the fire resistance barrier against fire. Mica-glass tape is the composite material which is composed of three components: support, binder and filler. As support is usually used glass fabric. Glass is the inorganic amorphous material with great thermal properties (Hassdenteufel, J., et al. 1978). Glass fabric has very good mechanical and electrical insulating properties. As the binder is mostly used polysiloxane - silicon resin (Mentlík et al., 2006). The function of the binder is compact interconnection of all components. Polysiloxane is an inorganic - organic polymer and it is thermoset. It consists of carbon, silicon and oxygen. Thermal stability is ensured due to structure of $-\mathrm{Si}-\mathrm{O}-\mathrm{Si}$ - . Silicone resin is hydrophobic. Silicon resin has good electrical and excellent thermal properties. Nevertheless the binder is the component of the composite insulation which is most influenced by degradation. Mica is one of the most applied insulating materials ever (Mentlík, 2006). Mica is used as a filler component in mica-glass tape. It means that it ensures electrical and thermal properties of the final composite material. Mica is an inorganic insulating material and it is very resistant in relation to degradation. Mica has excellent electrical insulating properties and it can withstand high temperatures. Mica is mainly applied as reconstructed mica. There are just two types of mica which can be used in electrical technology muscovite and phlogopite (properties of muscovite and phlogopite are shown in table 1). Muscovite has better electrical properties in comparison with phlogopite. On the other hand phlogopite has better thermal properties. On this account phlogopite is mostly applied for fire resistance cables.

\begin{tabular}{|l|c|c|c|}
\hline Properties & Muscovite & Phlogopite & Units \\
\hline Calcining temperature & $700-800$ & $900-1000$ & ${ }^{\circ} \mathrm{C}$ \\
\hline Permittivity $\varepsilon_{\mathrm{r}}$ & $6-7$ & $5-6$ & - \\
\hline Dissipation factor tg $\delta$ & $1-3.10^{-4}$ & $10-50.10^{-4}$ & - \\
\hline Electric strength & 60 & 45 & $\mathrm{kV} / \mathrm{mm}$ \\
\hline Volume resistivity & $10^{15}-10^{16}$ & $10^{12}-10^{14}$ & $\Omega \mathrm{cm}$ \\
\hline Operating temperature & $500-600$ & $800-900$ & ${ }^{\circ} \mathrm{C}$ \\
\hline
\end{tabular}

Tab. 1. Electrical and thermal properties of micas 


\section{DIAGNOSTIC SYSTEM}

Fire resistant cables are mechanically stressed during their production and operation. If the insulation is not equally designed, deformation by external forces can cause damage of insulation and the cable can lose its functionality. An important part of diagnosis (Mentlík et al., 2008) is to choose the diagnostic quantity which represents the mechanical stress of the cables. Measured cables were tested to observe whether they can be applied for nuclear energy. There are very strict criteria which cables must satisfy. One of these parameters is elongation at break which must be at least $50 \%$ according to International Atomic Energy Agency IAEA. Elongation at break was chosen as the diagnostic parameter.

\section{ELONGATION AT BREAK}

Elongation at break is one of the mechanical properties of materials and it is tested by elongation test according to standards (ČSN EN 60811-1-1). It is calculated after the breaking of the sample. Before the elongation test a test area is marked out in the middle of the sample which is called the initial length of sample $\mathrm{L}_{0}=20 \mathrm{~mm}$. The length of sample after its breaking was measured and marked as $\mathrm{L}_{\mathrm{U}}$. Elongation at break $\mathrm{A}$ is defined as the increment between initial length $\mathrm{L}_{0}$ and the length of the sample after its breaking $\mathrm{L}_{\mathrm{U}}$ relative to the initial length $L_{o}$ as it shows formula (1):

$$
A=\frac{L_{U}-L_{0}}{L_{0}} .100 \quad[\%]
$$

Where: A is elongation at break, $\mathrm{L}_{0}$ is initial length, $\mathrm{L}_{\mathrm{U}}$ is length of sample after breaking.

\section{EXPERIMENT}

Two types of cable were tested. The first type was JCXKEV/LOCA with a cross section of $0,8 \mathrm{~mm}^{2}$ and insulation made of cross-linked polyethylene XLPE with mica-glass tape. The second cable was JCXKE-R/LOCA with cross section of $0,8 \mathrm{~mm}^{2}$ and insulation made of cross-linked polyethylene XLPE. Supplement LOCA (Lost of Coolant Accident) is identification for cables which meet the requirements for application in nuclear energy. The measurement frequency was 20 for each type of insulation. The elongation test was carried out according to standard ČSN EN 60811-1-1 in the tensile testing machine. The distance of self-tightening clamps was $85 \mathrm{~mm}$ and the sample was fixed in the axis of self-tightening clamps. The feed speed of elongation was defined as $25 \mathrm{~mm}$ per minute. The sample preparation was carried out according to the standards (ČSN EN 60811-1-1). The core was pulled out from insulation of the core. The shape insulation of the core was a tube with defined length $100 \mathrm{~mm}$.

\section{RESULTS}

The elongation test for fire resistant cables with different types of insulation is shown in figure 2. Even though both tested cables are with cross-section $0,8 \mathrm{~mm}^{2}$ there is one big difference between the curves of each type of insulation. The blue represents insulation cross-linked polyethylene XLPE, shows that elongation at break is about $270 \%$. In the case of insulation cross-linked polyethylene with mica-glass tape it is evident that the breaking of mica-glass tape occurs very early. This breaking is represented as the peak in red line. This observation shows that the cable with insulation made of crosslinked polyethylene and the mica-glass tape lost its functionality at the time of the breaking of mica-glass tape. Elongation at break at this time is very difficult to determine. Additional insulation made of cross-linked polyethylene XLPE is not damaged and the elongation test runs on the time when the whole insulation is broken. Although it was written that the cross section of each insulation is $0,8 \mathrm{~mm}^{2}$, the mica-glass tape insulation has a different thickness. It is due to the tapping of the core with a required ratio of covering (usually 25-50\%) which evidently influenced the thickness of insulation.

\section{Elongation test}

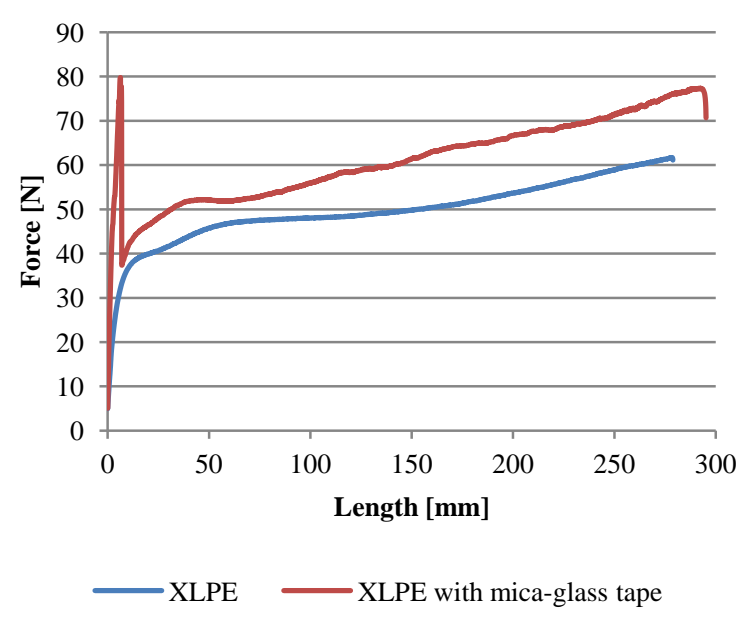

Fig. 2. Elongation test for fire resistant cables with different type of insulation

\section{CONCLUSION}

All obtained results confirmed that the elongation at the break of the insulation with mica-glass tape is less than insulation without mica-glass tape. It is necessary to consider that the cable with insulation which consisted of mica-glass tape lost its functionality at the time of breaking of mica-glass tape. As shown in the elongation test, mica-glass tape breaks early. The elongation at break of the tested fire resistance cables does not meet the requirement of at least $50 \%$ according to International Atomic Energy Agency IAEA.

\section{ACKNOWLEDGEMENTS}

This article was carried out with the support of Ministry of Education, Youth and Sports of Czech Republic, MSM 4977751310.

\section{REFERENCES}

ČSN EN 60811-1-1. V̌̌eobecné zkušebni metody izolačnich a pláštových materiálù elektrických kabelů. : Část 1: Metody pro všeobecné použití. Oddil 1: Měreni tlouštek a vnějšich rozměrů - Zkoušky pro stanoveni mechanických vlastností

Hassdenteufel, J., et al. (1978). Elektrotechnické materiály, Alfa Bratislava

IAEA-TECDOC-1188. (2000). Assessment and Management of Ageing of Major Nuclear Power Plant Components Important to Safety: In-Containment Instrumentation and Control Cables, Vol. I, IAEA, ISSN 1011-4289, Vienna

Mentlík, V. (2006). Dielektrické prvky a systémy, BEN technická literatura, ISBN 80-7300-189-6, Praha

Mentlík, V., et al. (2008). Diagnostika elektrických zařizení, BEN - technická literatura, ISBN 978-80-7300-232-9, Praha

Mentlík, V., Polanský, R., Pihera, J., Prosr, P., Trnka, P. (2006). The monitoring of property changes in insulating materials containing silicone binder, Electrical Insulation, Conference Record of the 2006 IEEE International symposium on electrical insulation, Toronto, ISSN 1089084X, ISBN 1-4244-0333-2, p. 366-368, Toronto, Ontario

Moore, G.F. (1997). Electric Cables Handbook, 3rd Edition, Blackwell Science Ltd., ISBN 978-0-632-04075-9, Oxford 